\title{
EFL MATERIALS IN MADRASAH TSANAWIYAH: WHAT DO THEY REALLY NEED?
}

\author{
Zuliati Rohmah \\ LAPIS-ELTIS and IAIN Sunan Ampel, Surabaya, Indonesia
}

\begin{abstract}
This study is a part of a larger research project, by a team of English Language Training for Islamic Schools (ELTIS), into the resources used in MTs. This paper talks about the needs of Islamic Junior High Schools (Madrasah Tsanawiyah, henceforth, MTs) for ELT materials. The research involved a number of principals, teachers and students of MTs in two areas: East Java and West Nusa Tenggara. Presentation and discussion of the analysis of the needs will be followed with some suggestions addressing some major weaknesses in the resources currently available in MTs.
\end{abstract}

Key words: English materials, Madrasah Tsanawiyah (MTs), East Java, West Nusa Tenggara

Instructional materials are indispensable in any ELT program (see e.g., Dow, 2004; Jahangard, 2007; Rahimi, 2008; Richards, 2007; Spratt et.al , 2005). Materials may include textbooks or coursebooks, video and audio tapes, computer software, and visual aids. Sheldon (1988) suggests that textbooks manifest the visible heart of any language teaching learning process. Coursebooks often determine the objectives of language learning and also often function as a lesson plan and working agenda for teachers and learners, although the ideal should be the vice versa. Cunningsworth (1995) argues that textbooks are an effective resource for autonomous learning, an effective resource for presentation material, a source of ideas and activities, a reference source for students, a syllabus where they reflect pre-determined learning objectives, and support for less experienced teachers who have yet to gain confidence. Therefore, materials play a vital role in learning processes.

In many cases, materials become the center of instructional processes. Coursebooks often influence the selection of the components and methods of learning. They also control the class and the learning processes. The choice of 
deductive vs. inductive learning, the role of memorization, the use of creativity and problem solving, production vs. reception, and the order in which materials are presented are all influenced by the materials (Kitao \& Kitao, 1997).

Looking at the importance of materials, it is good that the government has made some efforts to provide accessible and affordable materials for students. Up until 2005, principals and teachers selected and purchased books directly from publishers on a commission basis. This means that every year new books had to be purchased and students were unable to pass on books to younger siblings as the coursebooks would be different. This had led to financial difficulties for a great number of parents. The government has been attempting to regulate this by forbidding publishers from selling the books directly to school staff and forbidding the school staff as well from selling books directly to students. Teachers can only recommend that students or parents buy particular books from bookshops. This is a major change in policy and should help reduce corruption amongst school staff.

Bantuan Operasional Sekolah (BOS) Buku (School Operational Funding Program on Books) provides some funding dedicated specifically for the purchase of coursebooks to use in class. Each school is given a list of books recommended by the Board of National Standards of Education (henceforth, BSNP for short) and approved of by the Ministry of National Education. Schools usually prioritize the books according the kinds of subjects which are included in the National Exam, including English. The teachers and the school (madrasah) committee should meet to make deliberation and decide on which coursebooks to use. Books are then purchased using the BOS Buku funding. To avoid possible corrupt practice, there is an independent monitoring team, including members of the local community to monitor and observe the process. After receiving the coursebooks, schools have to 'lend' them to students to be used in class or at home. The textbooks should be returned to school at the end of the semester or school year, so they can be used by students of the next intake.

BOS and BOS Buku programs have, however, invited a number of criticisms. Firstly, the budget allocated for each student, i.e., Rp 20,000/student/subject, is insufficient. Secondly, the disbursement of the BOS Buku funding takes so long that schools or students have to pay first. This situation does not solve the main problem (Napitupulu, 2008). Third, the program has been prone to corruption (data manipulation, and price rigging and deals made between publishers and schools). The other problem is that many 
small scale MTs's are not registered; therefore, they are not eligible to receive the BOS funding.

The government has tried to solve these problems by proposing a new program called Buku Murah or e-Book, implemented in 2007 (Republika, 2008). This project involved the evaluation of coursebooks by the BSNP using specific criteria. The government then purchased and reserved the copyrights from selected writers. Last year, the government purchased 37 books for different subjects and levels. (None, however, was English book). These selected textbooks are then sold directly to schools.

The price of these coursebooks will be approximately one-third of the actual price. So, all students should, conceptually, be able to buy them. Any individual, organization, or company approved of by the Ministry of Religious Affairs (MoRA) or the Ministry of National Education (MoNE) can distribute, photocopy, or print the coursebooks (MoNE, 2008). The Minister of National Education has stated that the BOS Buku subsidy will be gradually reduced and ultimately, the Buku Murah Program will replace the need for BOS Buku funding. Unsurprisingly, there has been an outcry from publishers claiming that this project will undermine their role. The outcomes of the Buku Murah Program are as yet unclear.

This new state of affairs may benefit most MTs's where only $10 \%$ of them are state-run. Among 40,258 madrasahs in Indonesia, only 4,000 are fully funded by the government (Rohmah \& Bentley, 2007), whereas in fact, madrasahs are often the only educational institutions in isolated areas, and, therefore, tend to serve the poorest members of the society. The Buku Murah Program might be welcome in MTs without thorough consideration whether the books are in line with what they really need. Under this situation further questions arise as to what kinds of books are mostly used in MTs, what are the responses to them, what materials are actually needed in MTs, and whether the existing materials have already met the needs in MTs.

This article addresses the questions by relating them to class size and school facilities. This is because class size and school facilities may influence the choice of materials. Classes that consist of 15 students may need diferent materials and activities compared to those of 45 students. Similarly, schools that do not have any VCD player will not need any CDs. Cassettes will not be useful for schools that do not have any tape player. Therefore, a study on school's needs for materials necessitates data on the school size and facilities. 
Finally, clarifying what materials the schools really need is important to do in the efforts to provide better teaching-learning processes. Gathering information about the students' language learning needs and preferences is inevitable in this case (Dow, 2004). Understanding the students' needs is one step to make the materials useful, meaningful and interesting for students (Kitao \& Kitao, 1997).

\section{METHOD}

This section presents information about data collection, which includes points about the techniques for the data collection and participants or subjects involved in the study. The data for this study were collected through questionnaire, focused group discussions (FGDs) and interviews. The questionnaire asking about the resources used by teachers was distributed to 187 teachers in East Java (EJ) and 193 teachers in West Nusa Tenggara (WNT) who were involved in language upgrading courses administered by the ELTIS at IAIN Sunan Ampel Surabaya and Pusat Sumber Belajar Bersama (PSBB) MAN Mataram).

The FGDs were managed by selecting participants regularly attending the courses, had at least 2 years of teaching experience, and demonstrated willingness to offer opinions about the needs MTs for ELT materials. The selected subjects were then invited to attend 30-minute discussions. The discussion topics were similar to those in the questionnaires; however, this focused group discussions were expected to give more detailed information about the ELT materials used.

The interviews were carried out by visiting 6 schools in East Java and 7 schools in West Nusa Tenggara. The interviewees were MTs principals, English teachers, and randomly selected students. The aim of conducting the interviews was to collect information on class size, school facilities, allocation of the BOS Buku funding for ELT materials, interviewees' attitudes towards the importance of ELT in MTs, materials the teachers used to teach, what students liked or disliked about learning English and the methods which their English teachers used.

The data presented in this article, as noted earlier, are part of the total data collected by the ELTIS team in their attempts to provide supplementary materials suitable for the ELT needs in MTs. More complete data can be viewed in LAPIS-ELTIS (2008). 


\section{RESULT AND DISCUSSION}

As noted earlier, class size and school facilities, to a great extent, determine the needs for materials. In this regard, this section discusses points pertinent to class size, school facilities, and the schools' responses to the materials and the actual needs in.

\section{Class size}

As class size determines what kinds of materials suitable for students, the information on the number of students in each class is important to gather. The number of the students in the schools which were visited ranges from 67 to 602. Some schools have approximately $15-30$ students per class whilst larger schools, with more students, have $40-45$ students in each class.

According to some school principals, popular schools tend to have more students, while schools in remote areas that have competitors from other MTs's or SMPs tend to have fewer students. MTs N 1 Mataram, for example, has approximately 600 students. This relatively large student body is, to some extent, due to the good facilities, large building capacity, and strategic geographical location of the school. In contrast, MTs Hidayatul Muttaqin in Dangiang has 83 students and less than 20 students in each class. Accordingly, ELTIS materials suitable for MTs would need to be sufficiently flexible to cope with this wide range of different class.

\section{School Facilities}

The findings concerning the school facilities are categorized based on types and distribution of facilities as well as positive and negative views of the school principals and teachers.

Table 1. Positive and Negative Views on School Facilities

\begin{tabular}{|c|c|c|}
\hline \multirow{2}{*}{$\begin{array}{l}\text { Information from } \\
\text { MTs principals and } \\
\text { teachers }\end{array}$} & \multicolumn{2}{|l|}{ Facilities } \\
\hline & Positive & Negative \\
\hline $\begin{array}{l}\text { Cassettes, Tape play- } \\
\text { ers \& VCD players }\end{array}$ & $\begin{array}{l}\cdot 75 \% \text { of schools have } \\
\text { tape players, and around } \\
60 \% \text { have VCD players } \\
\text { - Teachers usually have } \\
\text { access to tape players }\end{array}$ & $\begin{array}{l}\text { - Only } 5 \% \text { say they have ever } \\
\text { used the tape player. This is be- } \\
\text { cause (1) most schools do not } \\
\text { have cassettes/CDs to accompany } \\
\text { the materials; (2) teachers do not } \\
\text { know what to do with them }\end{array}$ \\
\hline
\end{tabular}


Rohmah, EFL Materials in Madrasah Tsanawiyah 109

\begin{tabular}{|c|c|c|}
\hline \multicolumn{3}{|l|}{ Table Continued } \\
\hline TV & $\begin{array}{l}-80 \% \text { of schools have a } \\
\text { television and satellite } \\
\text { connectivity (donated by } \\
\text { ADB), but the TV set is } \\
\text { kept in the teachers' } \\
\text { room or the principal's } \\
\text { room for safety reasons }\end{array}$ & $\begin{array}{l}\text { - Only } 10 \% \text { of school principals } \\
\text { let teachers use the television for } \\
\text { educational purposes }\end{array}$ \\
\hline $\begin{array}{l}\text { Distribution of facili- } \\
\text { ties in different areas } \\
\& \text { additional facilities }\end{array}$ & $\begin{array}{l}\text { - Bigger schools tend to } \\
\text { have more facilities. The } \\
\text { more students, the more } \\
\text { funding a school re- } \\
\text { ceives. MTsN } 1 \text { Mataram } \\
\text { has a library, multimedia } \\
\text { room, language lab and } \\
\text { computer lab }\end{array}$ & $\begin{array}{l}\text { - MTs Hidayatul Muttaqin (in } \\
\text { Dangiang, West Lombok, around } \\
1.5 \text { hrs from Mataram) has very } \\
\text { few facilities; not enough chairs } \\
\text { or desks, a blackboard painted } \\
\text { onto the wall } \\
\text { - Only } 2 \% \text { of schools have a com- } \\
\text { puter lab, language laboratory } \\
\text { and/or a room with an LCD and } \\
\text { sound system (multimedia lab) }\end{array}$ \\
\hline
\end{tabular}

It can be viewed from the table that the resources in MTs's are mostly very limited. The schools that have VCD or tape players mostly do not have CDs or cassettes relevant for the English teaching and learning. This situation makes most teachers in MTs's unable to use the players. Moreover, when the facilities are available, e.g. TV, people in authority do not readily allow teachers to use them. The worst is that when the teachers are given access to the facilities, they do not have adequate knowledge and skills of how to use them to provide interesting, meaningful English teaching-learning activities.

Therefore, materials provided for MTs's should be appropriate for the mostly inadequate resources available in the schools and equipped with some training on the use of basic ELT audio-visual equipment such as tape recorders.

\section{Coursebooks}

Coursebooks are normally designed by professionals in the field with an understanding of principles behind task design, educational theory and the realities of teaching in the classroom. They can save a teacher time by providing ready-made lessons of professional appearance, especially in schools where teachers have limited access to other resources. They also give a structure to a course of work, since units are normally designed to be followed in a linear 
fashion. As they are produced in line with a curriculum, they usually contain guidance and practice for national exams. Coursebooks can give learners a sense of security. Learners can look ahead to see what is coming next and review what has been covered. In this way, coursebooks also provide the opportunity for self-study.

From the data collected through the questionnaire, it was found out that all coursebooks were those donated by MoRA, through BOS/BOS Buku funding and/or ADB projects. Related to coursebook selection, the data show some positive and negative aspects. The positive aspects include the following: 1) students do not have to buy textbooks because all textbooks are donated, 2) the school principals' role is to discuss the list of coursebooks from BOS Buku project with the teachers and allow them to choose what the teachers would like to use 3) schools often have a collection of English textbooks from many different publishers; this should benefit teachers more, for this means that they have some choices.

The negative aspects concerning the coursebook selection include the following points. First, one vice principal could not provide any information about the purchase of the coursebooks, for, as he said, the purchase was the sole responsibility of the head of the foundation (yayasan) or the cleric (Kyai). Second, all teachers said that they were never invited to talk about the coursebooks donated by MoRA. Third, all teachers were involved in the selection of the books donated through BOS Buku project; however, $60 \%$ of them said that the books purchased were different from the ones they had selected. Fourth, a collection of different books seemed to lead to confusion for both teachers and students. For example, MTs Raudhlatus Sholihin in Probolinggo had four different English coursebooks: 'Speak English First' (purchased using MoRA funding), 'Effective English' (MoRA funding), 'Let's Talk' and 'The Bridge English Competence' (BOS Buku funding). However, none of the books amounted to enough copies for a class set, and $80 \%$ of the teachers admitted that they were unsure about which books were in line with the Standar Isi (Standard of Contents). This explains why many coursebooks remain in the school library or staff room without any indication that they had been used.

With regard to frequency of use, over $60 \%$ of teachers in East Java (EJ) and $80 \%$ of teachers in West Nusa Tenggara (WNT) use coursebooks in every lesson. 50\% of teachers in EJ and WNT use different coursebooks interchangeably to provide variety. 
The research also tries to find the most commonly used textbooks in MTs. Three most commonly used textbooks in EJ are English on Sky (31\%), Effective English (13\%), and Let's Talk (8\%). Different books from various publishers are also used but the number is not significant. In WNT, the most commonly used textbooks are Let's Talk (34\%), Effective English (15\%), and English for Junior High School (14.8\%).

To know how the teachers gave responses to the most commonly used coursebooks, it is important to reveal some positive and negative comments gathered during the data collection. The positive comments on most commonly used coursebooks include the following: 1) all English teachers who use 'English on Sky' (31\% in EJ and 2\% in WNT) like the book because it is printed in color and comes with cassettes, 2) all English teachers who use 'Let's Talk' like the book due to the notion that it is easy to use and modify, 3) $20 \%$ of the teachers in EJ and in WNT said that each student received one book, and 4) regardless of many weaknesses of the existing coursebooks, $85 \%$ of the teachers said that they would keep using the existing coursebooks, for having a hold of new coursebooks is not easy. This last comment indicates that the teachers are not keen on learning new things. This can be related to the teachers' reluctance to change or learn new things.

The negative comments on most commonly used coursebooks include what follows. First, the teachers who use Effective English think that the book is confusing. Additionally, the teachers are not sure how to use certain activities. Second, no books have teachers' notes (guides) and/or answer keys. Third, most coursebooks used are still based on 1994 and 2004 curricula, as pointed out by $90 \%$ of the teachers. Fourth, the books do not come with accompanying cassettes or listening materials, as pointed out by $80 \%$ of the teachers. (English on Sky is the only book that comes with accompanying cassettes. This means that over $80 \%$ of the teachers in EJ and WNT do not have listening materials). Fifth, $80 \%$ of the students in both regions have to share one book among four students. Sixth, the instructions in the books are too difficult to understand and require translation (pointed out by $96 \%$ of the teachers). Seventh, $54 \%$ of the teachers in WNT and 60\% in EJ commented that there is no Islamic content in the available coursebooks. Eighth, $47 \%$ of the teachers have found difficulties covering everything in the coursebook. Ninth, $47 \%$ of the teachers found that the materials are dull and admitted that they wanted to make the materials more interesting. Tenth, $45 \%$ of the teachers pointed out that the coursebooks provide no balance of skills and contain mainly grammar exercises. And eleventh, 
$40 \%$ of the teachers commented on the difficulty level of the coursebooks for their students - the books are too difficult.

The data reveal that more negative comments on the most commonly used coursebooks have been expressed by the teachers. Therefore, it is not surprising that the teachers then make some adaptations. $80 \%$ of the teachers said that they sometimes adapt the coursebooks by simplifying the instructions, translating the texts, and reading the tape-script instead of using a cassette. Indeed, materials adaptation is often needed. As stated by Dow (2004), adaptation is still needed even though the coursebooks have been carefully written. This is because there is no perfect book that can meet all the teaching-learning needs that arise in any particular situation.

Looking at the way the teachers adapt the coursebooks, we can say that the adaptation is still limited. They merely simplify the instructions, translate the texts, and read the tape script when no cassette is available. In this regard, we can say that the teachers need many ideas on how to adapt the books. For instance, adaptation can be done by removing certain parts altogether or substituting them with other materials, adding more information/details/examples/exercises/pictures/activities, and removing pictures/examples/exercises/activities, etc. to suit the students' needs, school facilities, time allocation, and classroom atmosphere.

There are $20 \%$ of the teachers, however, that have never adapted the materials in the coursebooks because, as they feel, they do not have the knowledge or time to do it. The reason for the second situation can be understood, since most teachers in MTs are part-time teachers or volunteers, with the majority falling far short of government minimum service standards (Rohmah \& Bentley, 2007). They mostly teach because the situation forces them to teach; kids in the surrounding area need somebody to educate them, whilst at the same time, no government support is available to do so. Thus, on the one hand, the teachers teach because of the demand of their society although they have not had adequate qualification (and quality) to assume the job. On the other hand, they also need other activities to support their life. This is just like what is underlined by Kitao \& Kitao (1997), that is, many teachers are busy and do not have the time or inclination to prepare extra materials.

Realizing the situation, there should be good and practical materials produced to help the teachers in MTs teach English better. When the materials needed are fulfilled, it is reasonable to expect that the students are enthusiastic to learn English. Regarding the students' voices concerning the coursebooks, it 
was found that what they like most is reading and the related exercises. This is so probably because reading and the related exercises constitute what they are asked to do most for exams. $60 \%$ of the students considered grammar the most difficult and least enjoyable part of their coursebooks.

To deal with the grammar issue, discovery grammar learning can be introduced to the teachers so that they can teach grammar more interestingly. The teachers can start teaching reading and all activities related to it. When focus on grammar comes, the teachers can ask the students to identify certain forms and conclude by themselves the grammar rules they have learned. The teachers then can highlight the points and ask the students to provide further examples. This later on can be followed with guided speaking and freer speaking practices to end the session. Having these kinds of activities, the students will be trained to improve both their receptive skills and productive ones. The students will likely be happier because the activities will not be monotonous.

\section{Supplementary Materials}

Principals, teachers, and students were asked about what supplementary materials they had access to and what would most likely be used in their schools. All principals, teachers, and students referred to Lembar Kerja Siswa (Students' Worksheet), known as LKS, when asked about supplementary materials. In East Java, LKS is available to students in $66 \%$ of schools, while in WNT, only $33 \%$ have access to this kind of supplementary resources. Further information on the existing supplementary materials is shown in Table 2.

The study on the supplementary materials has revealed that apart from the LKS, MTs teachers have no access to, or at least are unaware of the possibility of using supplementary materials. The most frequently requested supplementary materials are games and visual aids, listening materials/cassettes and songs, Islamic contents (such as Islamic stories) and cross cultural understanding, exam practice/quizzes, speaking materials, reading materials, writing materials, and grammar materials. All of the teachers also requested teacher's notes/guides to accompany the materials or coursebooks.

The study also reveals that most of the school principals in MTs have recognized the importance of ELT and have been aware that there are some inaccuracies in the appointment of English teachers in their schools (some of the teachers do not have the relevant and needed qualification). 
114 TEFLIN Journal, Volume 20, Number 1, February 2009

Table 2. Comments on Supplementary Materials

\begin{tabular}{|c|c|c|}
\hline \multirow{2}{*}{$\begin{array}{l}\text { Information } \\
\text { from: }\end{array}$} & \multicolumn{2}{|l|}{ Existing supplementary materials } \\
\hline & Positive & Negative \\
\hline $\begin{array}{l}\text { MTs Princi- } \\
\text { pals }\end{array}$ & $\begin{array}{l}\text { - In } 40 \% \text { of schools, BOS and } \\
\text { BOS Buku funds were allocated to } \\
\text { purchase Lembar Kerja Siswa } \\
\text { (LKS), which cost about Rp } 3,500 \\
-4,000 / \text { LKS. This means that } \\
\text { LKS could be given free of } \\
\text { charge }\end{array}$ & $\begin{array}{l}\text { - } 80 \% \text { of Principals said there } \\
\text { were supplementary materi- } \\
\text { als available in the Princi- } \\
\text { pal's office and/or staffroom } \\
50 \% \text { of schools recom- } \\
\text { mended that students buy an } \\
\text { LKS } \\
10 \% \text { of schools set an obli- } \\
\text { gation that students should } \\
\text { by an LKS. However, some } \\
\text { students/parents are too poor } \\
\text { to purchase one } \\
80 \% \text { of principals said that } \\
\text { there were supplementary } \\
\text { materials available in the } \\
\text { Principal's office and/or } \\
\text { staffroom. However, there } \\
\text { was usually only one or two } \\
\text { copies of each resource }\end{array}$ \\
\hline
\end{tabular}

MTs English - all teachers stated they had no accessible supplementary materials Teachers other than LKS. The textbooks used have no accompanying LKS; LKS are published separately. Therefore, many of the activities in the $L K S$ are not related to the topics in the textbooks

- the content of the $L K S$ is usually only grammar exercises

The study also reveals that most of the school principals in MTs have recognized the importance of ELT and have been aware that there are some inaccuracies in the appointment of English teachers in their schools (some of the teachers do not have the relevant and needed qualification).

In addition, from students' perspective, the students also like English because, as they put it, "English is very important as it's an international lan- 
guage." This was the only reason given. The fact that students like their teachers to be friendly and patient requires attempts to help schools improve the quality of the English teachers. However, the issue of limited budget that most schools have has prevented them from sending their teachers to training or subject matter teachers' forums (known as MGMP). Thus, if teachers are offered workshop or training opportunities where the financial supports are available, such as those organized by the Department of Religious Affairs, the school principals are keen on sending their teachers to attend such fora.

As materials used in teaching partly determine the quality of teaching, there should be quality materials provided for MTs students which fulfill their needs. From the FGDs and interviews, it can be concluded that the materials intended to use in MTs should be easy to use. Thus, it should be practical. As learners said that they would like to have more exercises for self-study at home since they are not allowed to write any notes in the books or to take them home, there should be more books dedicated for their self-study. Since the activities they are likely to do most in class are conversations, games, songs, and group work, the coursebooks should facilitate and cater for those activities. As well, materials on exam are also needed because they want more reading exercises to help them prepare for the National Exam.

Teachers are comfortable with English on Sky and Let's Talk as coursebooks but would like the books to be updated so as to be in line with the changes in the curriculum. They also need to be equipped with supplementary materials to cope with or overcome the shortcomings in their coursebooks. This is meant to facilitate the teachers so that they feel confident that what they are teaching is in line with the curriculum.

\section{CONCLUSION}

In summary, considering the condition in most MTs's which suffer from limited financial supports, yet have positive responses to ELT enterprise, ELTIS and other parts interested in assisting to improve the quality of EFL in MTs's-MoRA is the most possible one- need to provide materials to fulfill the ELT needs of MTs's and to overcome the weaknesses in the existing materials. Other points to note include the following. First, the ELT materials for MTs should cater for teaching-learning activities in classes consisting of up to 45 students, appropriate for the limited resources available in some MTs's, and provide the teachers with guides. Second, supplementary materials should be 
made available for the teaching and learning of, for instance, listening. The materials should include pronunciation activities and be supported with recorded examples, since many MTs teachers feel insecure about their own pronunciation (this seems to be related to the fact that some English teachers are not English teachers by education: they do not have the formal qualification to assume the job, as noted earlier). The third point is that the materials should discuss Islamic values. The fourth point is that the materials should provide the teachers (and students) with fun activities: games, pictures, and songs. This is intended to cater for the students' tendency to be fond of fun activities. The last point is that the materials should provide intensive activities related to the students' preparation for the National Exam. This is meant to distill self-confidence on the part of the students to sit for the exam..

\section{REFERENCES}

Act of the Republic of Indonesia no. 20, year 2003 on National Education System, Chapter X, articles $36 \& 37$.

Appendix of the Ministry of National Education's Regulation no. 22, year 2006, Chapter II, Part A.2.b on the Principles of Curriculum Development, p. 4.

Cunningsworth, A. 1995. Choosing Your Coursebook. Oxford: Heinemann.

Dow, D.F. 2004. Evaluating _Classroom Teaching _Materials. (Online), (http://www.wheaton.edu/bgc/ICCT/ResandLinks/evaluating.html, retrieved 4 September 2009 ).

Jahangard, A. 2007. Evaluation of EFL Materials Taught at Iranian Public High Schools. Asian EFL Journal. (Online), Vol. 9, Issue 2, Article 7, (http://_www.asian-efl-journal.com/June_07-_aj.php', retrieved 4 September 2009).

Kitao, K. \& Kitao, S.K. 1997. Selecting and Developing Teaching/Learning Materials. The Internet TESL Journal._(Online), Vol. IV, No. 4, April 1997, (http://iteslj.org/Ärticles/Kitao-Materials.htmi, retrieved 4 September 2009).

LAPIS-ELTIS. 2008. Current State of ELT Materials for Madrasah Tsanawiyah: A Research Report. 
MoNE's Regulation no. 2, year 2008 on Books, Chapter VI, article 8, point (1)

Napitupulu, E.L. 2008. Putar Otak Siasati Terbatasnya Dana BOS. Kompas, 21 April, (Online),

hittp:///www.kompas.com/kompascetak.php/read/xmi /2008/04/21/0028185 , retireved 28 April 2008).

Rahimi, M. 2008. What Do We Want Teaching-Materials for in EFL Teacher Training Programs? Asian EFL Journal: Professional Teaching Articles. (Online), Vol. 31, chttp://www.asian-efl-journal.com/pta_Oct_08.pdf retrieved 8 Oct 2009)

Republika, 23 April,2008. Reformasi Buku Pelajaran ala Depdiknas. (Online), (http:///www.republika.co.id/koran.asp?kat_id=506, retrieved 24 April 2008).

Richards, J. C. 2007. Materials Development and Research: Towards a Formfocused Perspective. In S. Fotos and H. Nassaji. (Eds.), Form-Focused Instruction and Teacher Education Studies in Honor of Rod Ellis (p. 147160). Oxford: Oxford University Press.

Rohmah, Z. \& Bentley, C. 2007. English Language Training for Islamic Schools (ELTIS). Paper presented at TEFLIN International Conference 2007, UIN Syarif Hidayatullah, Jakarta (4-6 Desember 2007).

Sheldon, L. 1988. Evaluating ELT Textbooks and Materials. ELT Journal, 42 (4), 237-246.

Spratt, M., Pulverness, A., and Williams, M. 2005. The TKT Course. Cambridge: Cambridge University Press.

The Board of National Standards of Education (Badan Standar Nasional Pendidikan - BSNP). 2006. "The Guidelines of Syllabus Development of English for SMP/MTs" and "The Instruments of SMP/MTs English Textbooks Evaluation. 